\title{
Microbial Response to Charcoal Amendments of Highly Weathered Soils and Amazonian Dark Earths in Central Amazonia - Preliminary Results
}

Christoph Steiner ${ }^{1}$, Wenceslau G. Teixeira ${ }^{2}$, Johannes Lehmann ${ }^{3}$ and Wolfgang Zech $^{1}$

\section{1 \\ Introduction}

The abundance of charcoal and highly aromatic humic substances in Amazonian Dark Earths (ADE) suggests that residues of incomplete combustion of organic material (black carbon, pyrogenic carbon, charcoal) are a key factor for the persistence of soil organic matter (SOM) in ADE soils which contain up to 70 times more black carbon than the surrounding soils (Glaser et al. 2001). ${ }^{13} \mathrm{C}$-NMR studies showed that the only chemical structures that appear to survive decomposition processes are mostly due to finely divided charcoal (Skjemstad 2001). Generally, in highly weathered tropical soils, SOM and especially charcoal play a key role in maintaining soil fertility (Glaser et al. 2001, 2002).

Black carbon in soil has become an important research subject (Schmidt and Noack 2000) due to its likely importance for the global carbon (C) cycle (Kuhlbusch and Crutzen 1995). However, charred organic matter (OM) and black carbon in terrestrial soils have been rarely evaluated regarding their importance for nutrient supply and retention (Lehmann et al. 2003).

Addition of charcoal to soil was shown to affect various microbial processes in soil. For example, charcoal stimulates the colonization of crops by indigenous arbuscular mycorrhizal fungi (AMF). ${ }^{13} \mathrm{C}$ NMR and FTIR showed that charcoal is a microporous solid composed primarily of elemental (aromatic) $C$ and secondarily of carboxyl and phenolic C (Braida et al. 2003). Non-local density functional theory $\left(\mathrm{N}_{2}, \mathrm{Ar}\right)$ and Monte Carlo $\left(\mathrm{CO}_{2}\right)$ calculations revealed a porosity of $0.15 \mathrm{~cm}^{3} / \mathrm{g}$, specific surface area of $400 \mathrm{~m}^{2} / \mathrm{g}$, and appreciable porosity in ultramicropores of $<10 \AA$ (Braida et al. 2003). AMF can easily extend their extraradical hyphae into charcoal buried in soil and sporulate in the porous particles (Saito and Marumoto 2002). Those pores may offer a microhabitat to the AMF, which can obtain nutrients through mycelia extended from roots (Nishio 1996). The stimulation of AMF due to charcoal is relatively well known, although in practice limited due to its high cost (Nishio 1996; Saito and Marumoto 2002). In a slash and char agricultural

\footnotetext{
${ }^{1}$ Institute of Soil Science, University of Bayreuth, 95440 Bayreuth, Germany

${ }^{2}$ Embrapa Amazônia Ocidental, 69011-970 Manaus, Brazil

${ }^{3}$ Department of Crop and Soil Sciences, Cornell University, Ithaca, New York 14853, USA
} 
practice as an alternative to slash and burn (Lehmann et al. 2002), the costs of charcoal application could be low enough to be profitable (Steiner et al. 2003). Nishio (1996) showed that charcoal can improve nodule formation, nodule weight (2.3 times), and nitrogen uptake (2.8-4 times). Charcoal particles have a large number of continuous pores. Pietikainen et al. (2000) found that charcoal itself supported a microbial community which was small but more active than that of humus. Microcosm studies showed that bacterial growth rate $(\mathrm{k})$ and basal respiration (BR) were higher in charcoal treatments compared to treatments without charcoal. Charcoal has the capacity to adsorb plantgrowth-inhibiting organic compounds and may form a new habitat for microbes, which decompose the absorbed compounds (Pietikainen et al. 2000). In the presence of charcoal, seedling shoot and root ratios and nitrogen uptake of a tree species (Betula pendula) were enhanced (6.22 times) but only if humus phenolics produced by ericaceous vegetation was present in a boreal forest ecosystem. Fern prothalli were entirely absent in ericaceous substrate unless charcoal was also present. Charcoal maintains a high sorptive capacity for about a century after wildfire, and this sorption is potentially capable of reversing the negative effects of plant species that produce high levels of phenolics (Wardle et al. 1998). Fischer and Bienkowski (1999) and Uvarov (2000) investigated respiration of soil community and decomposition rate of SOM after long-term exposure to smoke emissions from charcoal production in Poland. They found that soil systems in the neighborhood of charcoal kilns have generally a higher level of biological activity. The average density of seedlings was significantly higher in the contaminated soils in comparison with the soils in uncontaminated forest (Uvarov 2000). These examples illustrate the important effects of charcoal on soil ecological processes.

Microorganisms transform and recycle $\mathrm{OM}$ and plant nutrients in the soil and are sinks (during immobilization) and sources (during mineralization) of labile nutrients (Stenström et al. 1998). Immobilization could be important as a nutrient retention mechanism in those soils highly affected by leaching. On the other hand, phosphorus $(\mathrm{P})$ is strongly bound to aluminum and iron oxides and is thus not available for plants. Heterophobic phosphatesolubilizing microorganisms make mineral-bound phosphate available by the excretion of chelating organic acids. Microorganisms need large amounts of organic matter before they can excrete organic acids (Nishio 1996). The phosphate and other plant nutrients become available after the $\mathrm{OM}$ becomes exhausted and microbial biomass decreases, releasing nutrients into the soil. Kimura and Nishio (1989) showed that insoluble phosphates that are not crystallized can be solubilized by indigenous microorganisms when abundant carbon sources are supplied.

Mainly Japanese farmers utilize microorganisms in the hope of increasing the yield or quality of their crops at a relatively low cost (Nishio 1996). AMF inocula are useful to reduce phosphate fertilizer application.

The microbial biomass can serve as an indicator of the effect of charcoal applications as microbial biomass was shown to react significantly to differ- 
ent management practices (Stenström et al. 1998). Substrate-induced respiration (SIR) also serves to assess the potential performance of microorganisms and this provides hints for nitrogen supply potential, and availability of organic compounds or inhibiting agents like toxic materials (Beck and Bengel 1992).

Therefore, microbial respiration was measured to gain information about the changes in the fertility and quality of tropical soil amended with organic and mineral fertilizers over a 2-year period. We investigated the long-term effects of $\mathrm{OM}$ additions in the form of particulate charcoal with respect to its sustainability and resilience against microbial decomposition by investigating ADE. Most models dealing with the turnover of soil organic carbon include a soil carbon pool that either is inert or has a turnover time measured in centuries or millennia (Goldammer 1993; Goudriaan ; Kuhlbusch and Crutzen 1995; Kuhlbusch et al. 1996; Skjemstad et al. 1996; Trumbore et al. 1996; Schmidt and Noack 2000; Verburg et al. ). The strongest evidence of the presence of such a pool comes from radio carbon dating of soils that shows that in some cases, even in surface horizons, the mean resistance time for organic carbon exceeds 1,000 years. A strong interaction with the mineral matrix, chemical recalcitrance imparted through strong humification processes, and the presence of significant quantities of finely divided charcoal are the main mechanisms for imparting SOM resistance (Skjemstad 2001). Finely divided charcoal was applied in the experimental field and was studied in respect to microbial respiration in comparison to other organic amendments. Large quantities of charcoal are found in ADE, which is the key for the recalcitrance of the OM (Glaser et al. 2000). Additionally, the suitability of this method to investigate properties of tropical soils under different management was of interest.

\section{2 \\ Material and Methods}

This study was conducted at the Embrapa (Empresa Brasileira de Pesqusa Agropecuária) Amazônia Ocidental station, near Manaus, Brazil. The average

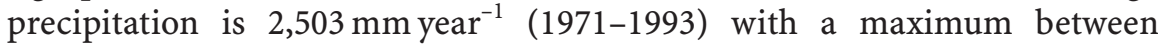
December and May. The natural vegetation is tropical rainforest. The soils are classified as Xanthic Ferralsols (FAO 1990) and are clayey (with over $80 \%$ clay) and strongly aggregated.

\subsection{1}

\section{Study Design}

OM amendments to soil (charcoal powder $\mathrm{C}_{\mathrm{C}}$, chicken manure $\mathrm{C}_{\mathrm{M}}$, compost $\mathrm{C}_{\mathrm{O}}$, and litter $\mathrm{L}$ ) were tested in a field experiment with respect to their effect on microbial respiration of soil. Respiration curves of top soil samples $(0-10 \mathrm{~cm})$ were determined in 13 treatments comprising different combina- 


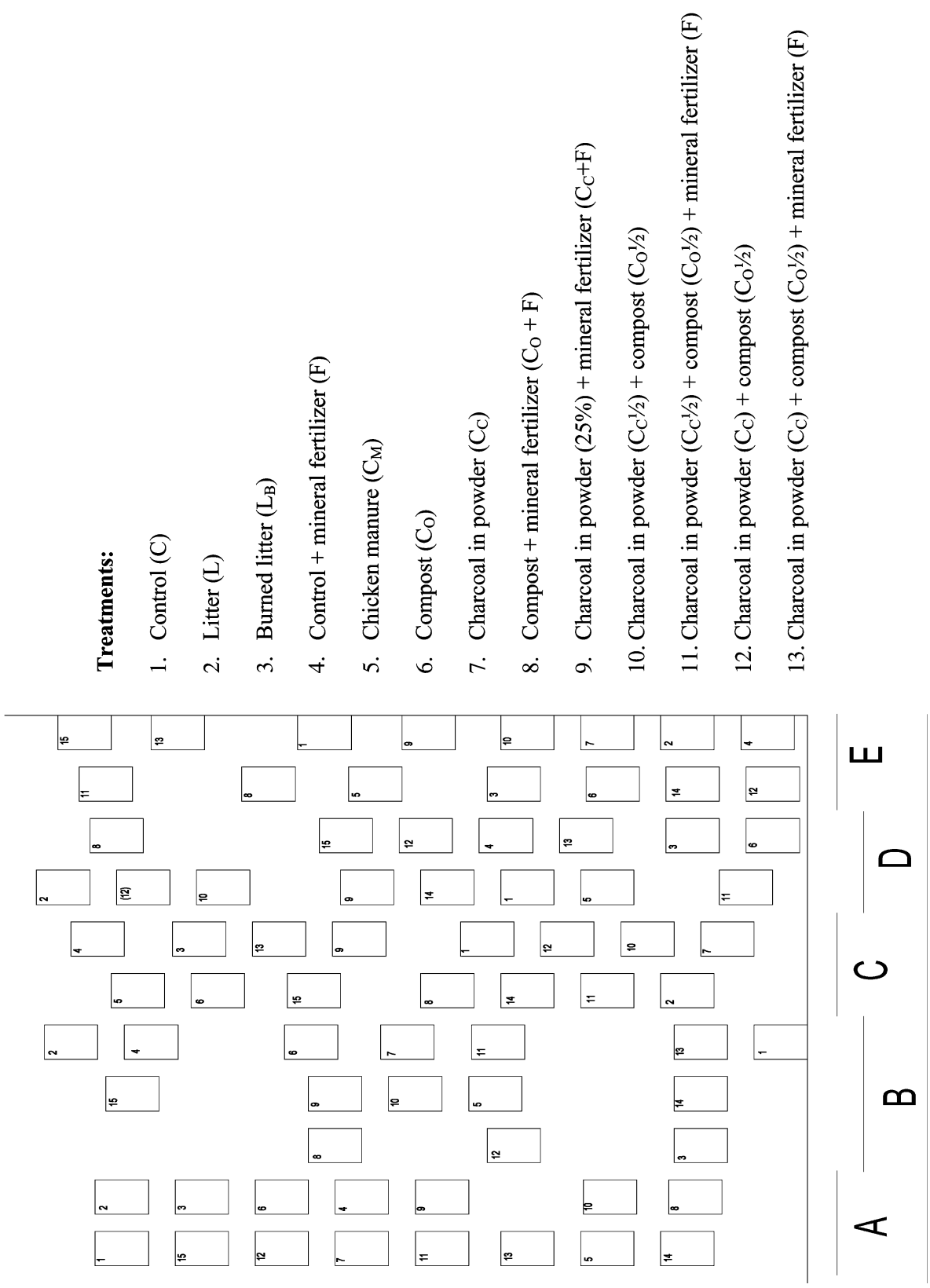

Fig. 15.1. Field plan with spatial layout of the experimental plots; letters show the five replicates $A, B, C, D$, and $E$, each including the 13 treatments applied on $2-\mathrm{m}^{2}$ plots 
tions of organic amendments in August 2001 and November 2002. The experiment was laid out in a randomized complete block design using five replicates (Fig. 15.1).

Vegetation litter and root material were removed from the entire field area $(45 \times 35 \mathrm{~m})$ and aluminum sheets were used as erosion controls between the plots. The treatments were applied on $4-\mathrm{m}^{2}$ plots $(2 \times 2 \mathrm{~m})$ and the amount of applied $\mathrm{OM}$ was calculated from the total $\mathrm{C}$ content of the materials to increase total soil $\mathrm{C}$ content in the 0 - to 10 -cm depth by $25 \%$ (Fig. 15.1).

Table 15.1. Amounts of additions of organic matter (February 2001) and mineral fertilizer (March 2001 and April 2002) to a Xanthic Ferralsol in central Amazonia

\begin{tabular}{|c|c|c|c|}
\hline Treatment & $\begin{array}{l}\text { Organic matter type } \\
\text { February } 2001 \\
\left(\mathrm{kgha}^{-1}\right)\end{array}$ & $\begin{array}{l}\text { Mineral fertilizer type } \\
\text { March } 2001 \\
\left(\mathrm{~kg} \mathrm{ha}^{-1}\right)\end{array}$ & $\begin{array}{l}\text { Mineral fertilizer type } \\
\text { April } 2002 \\
\left(\mathrm{~kg} \mathrm{ha}^{-1}\right)\end{array}$ \\
\hline $\mathrm{C}$ & None & None & None \\
\hline $\mathrm{L}$ & Litter $(13,000)$ & None & $\begin{array}{l}\mathrm{N}(55), \mathrm{P}(40), \mathrm{K}(50), \\
\text { lime }(2,800), \mathrm{Zn}(7), \\
\mathrm{B}(1.4), \mathrm{Cu}(0.6), \mathrm{Fe}(2.3), \\
\text { Mn (1.6), Mo (0.08) }\end{array}$ \\
\hline $\mathrm{L}_{\mathrm{B}}$ & $\begin{array}{l}\text { Burned litter } \\
\text { (13,000 dry litter } \\
\text { before burning) }\end{array}$ & None & $\begin{array}{l}\mathrm{N}(55), \mathrm{P}(40), \mathrm{K}(50) \\
\text { lime }(2,800)\end{array}$ \\
\hline $\mathrm{F}$ & None & $\begin{array}{l}\mathrm{N}(30), \mathrm{P}(35), \mathrm{K}(50) \\
\text { lime }(2,100)\end{array}$ & $\begin{array}{l}\mathrm{N}(55), \mathrm{P}(40), \mathrm{K}(50) \\
\text { lime (430) }\end{array}$ \\
\hline $\mathrm{C}_{\mathrm{M}}$ & $\begin{array}{l}\text { Chicken manure } \\
(47,000)\end{array}$ & None & None \\
\hline $\mathrm{C}_{\mathrm{O}}$ & Compost $(67,000)$ & None & None \\
\hline $\mathrm{C}_{\mathrm{C}}$ & Charcoal $(11,000)$ & None & None \\
\hline $\mathrm{C}_{\mathrm{O}}+\mathrm{F}$ & Compost $(67,000)$ & $\begin{array}{l}\mathrm{N}(30), \mathrm{P}(35), \mathrm{K}(50) \\
\text { lime }(2,100)\end{array}$ & $\begin{array}{l}\mathrm{N}(55), \mathrm{P}(40), \mathrm{K}(50) \\
\text { lime (430) }\end{array}$ \\
\hline $\mathrm{C}_{\mathrm{C}}+\mathrm{F}$ & Charcoal $(11,000)$ & $\begin{array}{l}\mathrm{N}(30), \mathrm{P}(35), \mathrm{K}(50) \\
\text { lime }(2,100)\end{array}$ & $\begin{array}{l}\mathrm{N}(55), \mathrm{P}(40), \mathrm{K}(50) \\
\text { lime (430) }\end{array}$ \\
\hline $\mathrm{C}_{\mathrm{C}}{ }^{1} /{ }_{2}+\mathrm{C}_{\mathrm{O}}{ }^{1} / 2$ & $\begin{array}{l}\text { Charcoal }(5,500), \\
\text { compost }(33,500)\end{array}$ & None & None \\
\hline $\mathrm{C}_{\mathrm{C}}{ }^{1} /{ }_{2}+\mathrm{C}_{\mathrm{O}}{ }^{1} /{ }_{2}+\mathrm{F}$ & $\begin{array}{l}\text { Charcoal }(5,500), \\
\text { compost }(33,500)\end{array}$ & $\begin{array}{l}\mathrm{N}(30), \mathrm{P}(35), \mathrm{K}(50) \\
\text { lime }(2,100)\end{array}$ & $\begin{array}{l}\mathrm{N}(55), \mathrm{P}(40), \mathrm{K}(50) \\
\text { lime }(430)\end{array}$ \\
\hline $\mathrm{C}_{\mathrm{C}}+\mathrm{C}_{\mathrm{O}}{ }^{1} / 2$ & $\begin{array}{l}\text { Charcoal }(11,000) \text {, } \\
\text { compost }(33,500)\end{array}$ & None & None \\
\hline $\mathrm{C}_{\mathrm{C}}+\mathrm{C}_{\mathrm{O}}{ }^{1} /{ }_{2}+\mathrm{F}$ & $\begin{array}{l}\text { Charcoal }(11,000) \text {, } \\
\text { compost }(33,500)\end{array}$ & $\begin{array}{l}\mathrm{N}(30), \mathrm{P}(35), \mathrm{K}(50) \\
\text { lime }(2,100)\end{array}$ & $\begin{array}{l}\text { N (55), P (40), K (50), } \\
\text { lime (430) }\end{array}$ \\
\hline
\end{tabular}


Mineral fertilizer (NPK and lime) was applied as recommended by Embrapa (Fageria 1998). Organic materials were applied just once at the beginning of the experiment ( 3 February 2001). Mineral fertilizer was applied in March 2001 and after the second harvest in April 2002 (Table 15.1). Crop residues were not removed from the plots. As a first crop, rice (Oryza sativa L.) was planted followed by three repeated sorghum (Sorghum bicolor L. Moench) crops. Sole compost amendments $\left(\mathrm{C}_{0}\right)$ was only studied in the second year due to a broken chamber in the measuring device.

\subsection{2}

\section{Soil Sampling and Analyses}

Soil samples $(0-10 \mathrm{~cm})$ were taken after the first harvest in August 2001 and after the fourth harvest in November 2002. In addition, 29 soil samples from 5 different archaeological sites covered by ADE (locally known as terra preta de indio) [Embrapa - Estaçao Experimental do Caldeirão - Iranduba $(n=14)$, Fazenda Jiquitaia - Rio Preto da Eva $(n=4)$, Lago da Valéria - Parintins $(n=4)$, Ramal Acutuba ( $n=9)$, TP Ramal das Laranjeiras $(n=2)]$, plus 5 primary forest and 5 secondary forest sites were sampled and analyzed. For basic soil characterization, we analyzed the soil samples for nitrogen $(\mathrm{N})$, phosphorus $(\mathrm{P})$, magnesium $(\mathrm{Mg})$, calcium $(\mathrm{Ca})$, and potassium $(\mathrm{K})$ and measured the $\mathrm{pH}$. For the extraction of exchangeable $\mathrm{P}, \mathrm{K}, \mathrm{Ca}$, and $\mathrm{Mg}$, the Mehlich-3 extraction method was used without modification (Mehlich 1984). The filtered solutions were analyzed for $\mathrm{P}, \mathrm{K}, \mathrm{Ca}$, and $\mathrm{Mg}$ using atomic absorption spectrometry (AA-400, Varian Associates, Inc., Palo Alto, California). Total $\mathrm{C}$ and $\mathrm{N}$ were analyzed by dry combustion with an automatic $\mathrm{C} / \mathrm{N}$ Analyzer (Elementar, Hanau, Germany). The soil $\mathrm{pH}$ was determined in water and $\mathrm{KCl}$ using an electronic $\mathrm{pH}$ meter with a glass electrode (WTW $\mathrm{pH}$ 330). Deionized water and $1 \mathrm{M} \mathrm{KCl}$ were applied in the ratio 1:5 soil:dilution medium.

The soil was sieved $(<4 \mathrm{~mm})$, humidity was measured, and the samples were stored overnight in darkness at $20^{\circ} \mathrm{C}$. Microbial biomass was determined using basal and substrate-induced respiration (SIR). Respiration measurements were performed with the IRGA-based (infra-red gas analysis) ECT-Soil Respiration Device (ECT Oekotoxikologie GmbH, Germany) according to the procedure described by Anderson and Domsch (1878) and Förster and Farias (2000). The respiration of soil samples ( $40 \mathrm{~g}$ dry weight) was determined by measuring the carbon dioxide $\left(\mathrm{CO}_{2}\right)$ production over time in a continuous flow system at a constant flow rate of $300 \mathrm{ml}$ fresh air min $^{-1}$. A portable computerized photosynthesis measuring system HCM1000 (Heinz Walz GmbH, Effeltrich, Germany) was used for $\mathrm{CO}_{2}$ measurement. The central unit of the system consists of an IRGA, a peristaltic air pump, and a mass flow meter that is connected to a measuring chamber (cuvette). It operates in an open flow mode (differential mode), measuring the difference between the $\mathrm{CO}_{2}$ concentration of the ambient air before and 
after passing the cuvette. The system is controlled via a computer. To measure soil respiration the central unit was connected to a specially designed rag containing 17 cuvettes. Each cuvette was connected via tubing and solenoid valves to the central unit.

Microbial respiration was measured for $12 \mathrm{~h}$. After glucose addition the measurement continued for an additional $24 \mathrm{~h}$ (SIR). Each soil sample was measured once within $1 \mathrm{~h}$ over a period of up to $50 \mathrm{~h}$. The SIR method is a physiological method for the measurement of the soil microbial biomass. When easily degradable substrates, such as glucose, are added to a soil, an immediate increase of the respiration rate is obtained, the size of which is assumed to be proportional to the size of the microbial biomass (Stenström et al. 1998). The basal respiration is measured before the addition of the substrate and the SIR shortly after the substrate $(240 \mathrm{mg}$ glucose) addition. Microbial respiration was calculated according to:

Respiration $\left[\mathrm{nL} \mathrm{CO}_{2} \mathrm{~min}^{-1} \mathrm{~g}^{-1}\right.$ soil $]=\left(\mathrm{C}^{\star} \mathrm{F}\right) / \mathrm{S}$

where $\mathrm{C}$ is the IRGA-measured $\mathrm{CO}_{2}$ value (ppm), $\mathrm{F}$ is flow rate through the cuvette $\left(\mathrm{ml} \mathrm{min}^{-1}\right)$, and $\mathrm{S}$ is soil dry weight $(\mathrm{g})$.

Microbial biomass was calculated according to Anderson and Domsch (1978):

Microbial biomass $\left(\mathrm{C}_{\text {mic }}\left[\mu \mathrm{g} \mathrm{C}_{\text {mic }} \mathrm{g}^{-1}\right.\right.$ soil $]=\left(\mathrm{R}^{\star} 40.04\right)+0.37$

where $\mathrm{R}$ is respiration $\left(\mu \mathrm{l} \mathrm{CO}_{2} \mathrm{~g}^{-1} \mathrm{~h}^{-1}\right)$.

The specific respiration increment was quantified as the slope of the exponential respiration increase after substrate addition when the respiration rate is plotted on a scale against time. This slope was described by:

$\mathrm{M}=\mathrm{N}_{0} \mathrm{e}^{\mathrm{kt}}$

where $\mathrm{N}_{0}$ is the initial concentration of microorganisms, $k$ is the specific growth rate, and $t$ is time.

The following parameters served as indicators of soil quality, OM turnover, and nutrient availability (Fig. 15.2): basal respiration (BR), substrate-induced respiration (SIR), velocity of population increase $(\mathrm{k})$ after substrate addition (nutrient availability and soil quality), activation quotient $(\mathrm{QR}=\mathrm{BR} / \mathrm{SIR}$, microbial efficiency), $\mathrm{C}_{\text {mic }} / \mathrm{C}_{\text {org }}$ (population density independent from $\mathrm{OM}$ content), and metabolic quotient $\left(\mathrm{CO}_{2}-\mathrm{Ch}^{-1} \mathrm{C}_{\text {mic }}{ }^{-1}\right)$.

In order to study the decomposition rate of rice straw (first harvest), five litterbags were deposited on each plot on the soil surface in July after the first harvest. The bags with a mesh size of $1 \times 1 \mathrm{~mm}$ contained $5 \mathrm{~g}$ dry biomass not excluding macrofauna entirely. The litterbags were collected after 7, 15, 30,60 , and 120 days and were dried at $60^{\circ} \mathrm{C}$ for $48 \mathrm{~h}$ and weighed. An exponential regression was applied in order to calculate the decomposition time of the rice straw. 


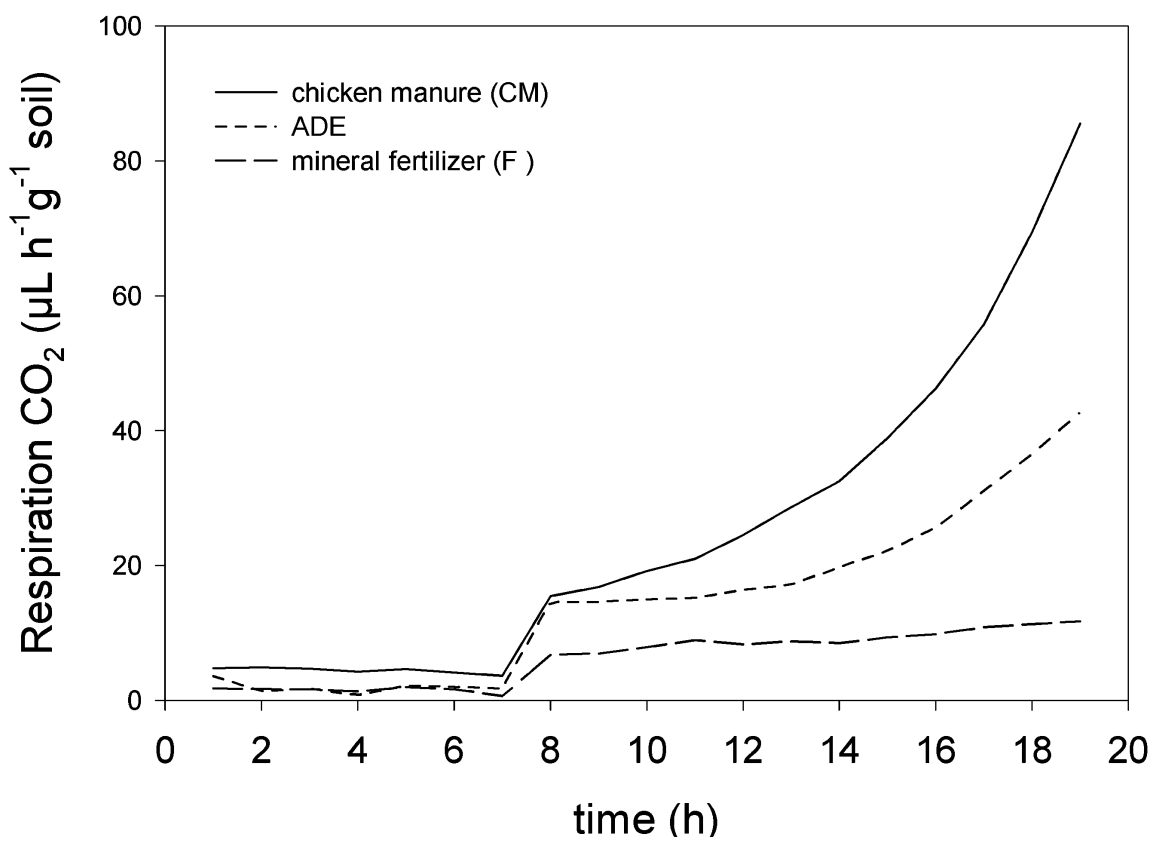

Fig. 15.2. Respiration curves of Xanthic Ferralsols amended with mineral fertilizer $(F)$, soil with chicken manure $(C M)$, as well as an ADE. Manure and mineral fertilizer were applied 6 months before soil sampling. Parameters basal respiration $(B R)$, substrate-induced respiration $(S I R)$, and the slopes $(k)$ are marked. Substrate (glucose) was added after $7 \mathrm{~h}$

\subsection{3}

\section{Statistical Analyses}

Statistical analyses were performed using Sigma Stat32 (Jandel Corporation). To evaluate the differences in the mean values among the treatments, a twoway analysis of variance (ANOVA) was performed and the Student-NewmanKeuls Method was used to detect significant differences between treatments $(p<0.05)$. The Pearson Product Moment Correlation was performed to assess the correlation between the measured parameters. The field plan was drawn with CorelDRAW (Corel Corporation) and the plots were made using SigmaPlot (SPSS Inc.).

\section{3}

\section{Results and Discussion}

The soil microbial population growth rate $(\mathrm{k})$ after substrate addition shows a significant positive correlation to nutrient availability in the soil. The studied primary and secondary forest soils had no or negative population growth after glucose addition despite their relatively high nitrogen levels and were 
not included in the correlation. The highest correlation coefficients $(r)$ and lowest $p$ values were found for $\mathrm{Ca}(r=0.650, p<0.001), \mathrm{Mg}(r=0.595, p$ $<0.001)$, and $\mathrm{K}(r=0.608, p<0.001)$, which indicates a $\mathrm{pH}$ dependency $(\mathrm{pH}$ in $\mathrm{H}_{2} \mathrm{O} r=0.534 p<0.001, \mathrm{pH}$ in $\left.\mathrm{KCl} r=0.579, p<0.001\right)$. The correlation coefficient for $\mathrm{P}$ was 0.490 and for $\mathrm{N} 0.561(p<0.001)$.

The nutrient contents $(\mathrm{K}, \mathrm{Mg}, \mathrm{Ca}$, and $\mathrm{P}$ ) and $\mathrm{pH}$ values (in water and $\mathrm{KCl}$ ) of the chicken manure treatment $\left(\mathrm{C}_{\mathrm{M}}\right)$ are significantly different to all other treatments [excluding ADE, primary (PF), and secondary forest (SF), for which insufficient nutrient data for $\mathrm{Mg}, \mathrm{Ca}, \mathrm{K}$, and $\mathrm{P}$ contents were available]. The $\mathrm{N}$ levels do not differ between the treatments. ADE showed a significantly higher $\mathrm{N}$ content in comparison to all other soils $(p<0.05$, two-way ANOVA, and Student-Newman-Keuls post hoc comparison, Table 15.2).

Excluding the chicken manure treatment, $\mathrm{pH}$ in water is significantly higher in treatment $\mathrm{F}$ (control + NPK + lime) than in the unfertilized (NPK + lime) soils $\left(\mathrm{C}, \mathrm{L}, \mathrm{L}_{\mathrm{B}}, \mathrm{C}_{\mathrm{C}}, \mathrm{C}_{\mathrm{C}}{ }^{1} /{ }_{2}+\mathrm{C}_{\mathrm{O}}{ }^{1} / 2, \mathrm{C}_{\mathrm{C}}+\mathrm{C}_{\mathrm{O}}{ }^{1} / 2\right)$. Measured in $\mathrm{KCl}$ the $\mathrm{pH}$ in treatment $\mathrm{F}$ and $\mathrm{C}_{\mathrm{C}}+\mathrm{F}$ (charcoal, NPK + lime) is significantly higher than the unlimed soils apart from treatment $\mathrm{C}_{\mathrm{C}}{ }^{1}{ }_{2}+\mathrm{C}_{\mathrm{O}}{ }^{1} / 2$ (the compost used for the experiment contained lime). The Mg contents are significantly increased due to liming in comparison to all unlimed treatments. Significant differences in the Ca levels are just manifested if no compost was added (Table 15.2).

The microbial population size and the microbial population growth $(\mathrm{k})$ after substrate addition correlate significantly with plant biomass production (first biomass yield $r=0.754, p<0.001$ and $r=0.756, p<0.001$, respectively). The fourth biomass yield correlates significantly with $\mathrm{k}$ and microbial biomass derived from samples taken in the year 2002 after the harvest $(r=0.700$, $p<0.001$ and $r=0756, p<0.001$, respectively). Due to their high $\mathrm{OM}$ and nutrient (mainly $\mathrm{P}$ and $\mathrm{Ca}$ ) contents, chicken manure amended soils $\left(\mathrm{C}_{\mathrm{M}}\right)$ showed significantly enhanced basal respiration and microbial population growth rates in comparison to all other treatments, secondary forest, and primary forest. Soil respiration curves can serve as a fast indicator of soil fertility, providing the same or similar results as plant biomass production (Fig. 15.3).

First-year respiration curves reflect clearly the level of fertilization (Fig. 15.4). BR, SIR, and microbial biomass are significantly enhanced in the plots treated with chicken manure and with mineral fertilizer (Table 15.3). The values obtained for the control coincide with those obtained by Förster and Farias (2000) in the same study area. The respiration curves after the fourth harvest are clearly diminished although to a lesser extent in the OM (charcoal)-treated plots (Table 15.4 and Fig. 15.5). The microbial growth rate after substrate addition is significantly enhanced in mineral-fertilized charcoal amended plots $\left(\mathrm{C}_{\mathrm{C}}+\mathrm{F}\right)$ in comparison to just mineral-fertilized plots $(\mathrm{F})$. This difference supports the hypothesis that charcoal additions reduce nutrient leaching and/or microbes are able to solubilize phosphate to a greater extent. Treatment $\mathrm{L}$ (litter) shows a significantly increased $\mathrm{BR}$ in comparison to other unfertilized plots $\left(\mathrm{C}, \mathrm{C}_{\mathrm{C}}, \mathrm{C}_{\mathrm{C}}{ }^{1}{ }_{2}+\mathrm{C}_{\mathrm{O}}{ }^{1} / 2\right.$, and $\left.\mathrm{C}_{\mathrm{C}}+\mathrm{C}_{\mathrm{O}}{ }^{1} / 2\right)$. This could be 


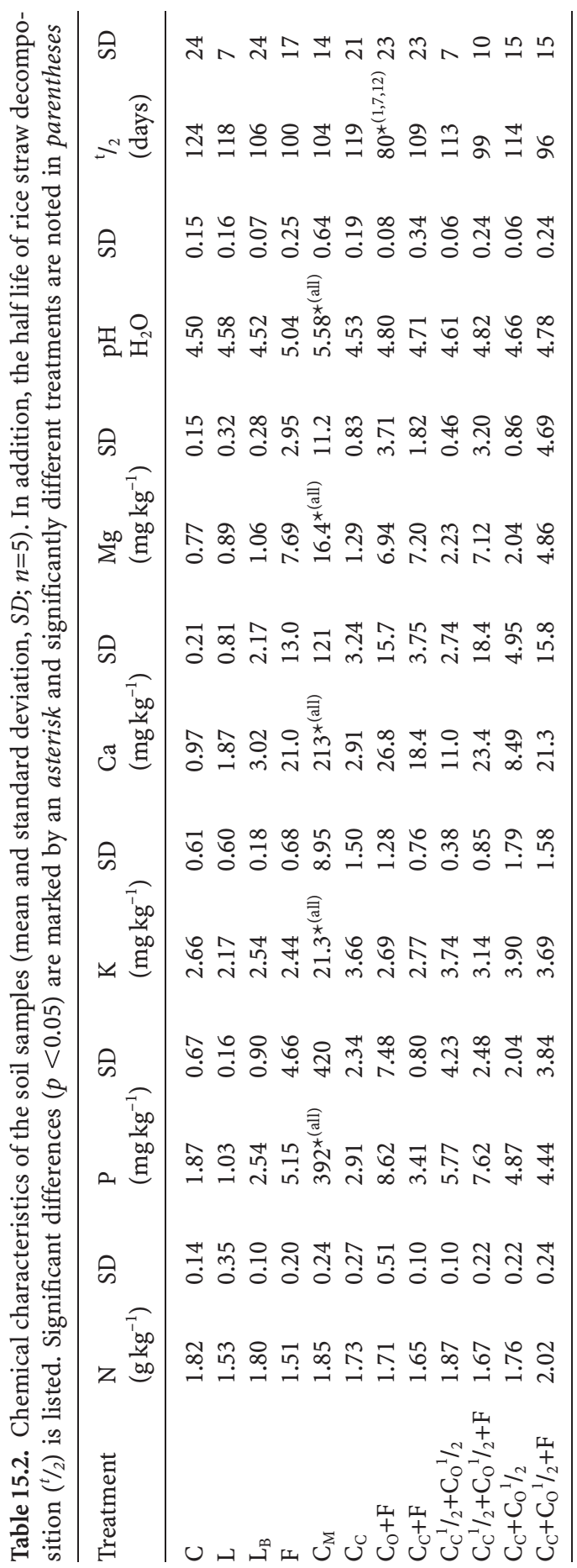




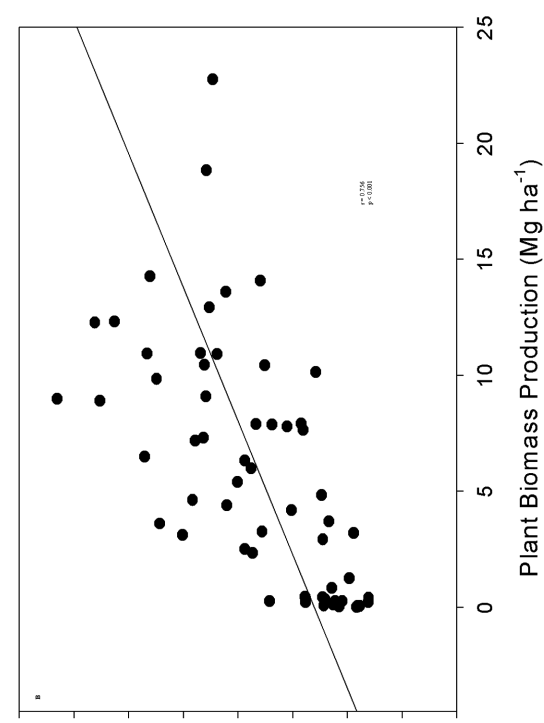

옹 옹 융 암 융

(I!Os L- 6 ว 6n) ssemo!g |e!qodग!W

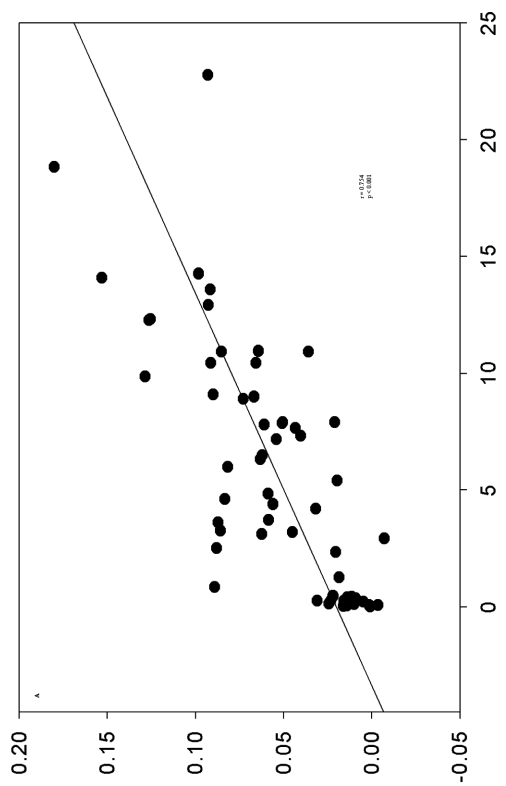

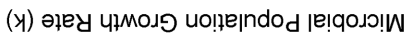
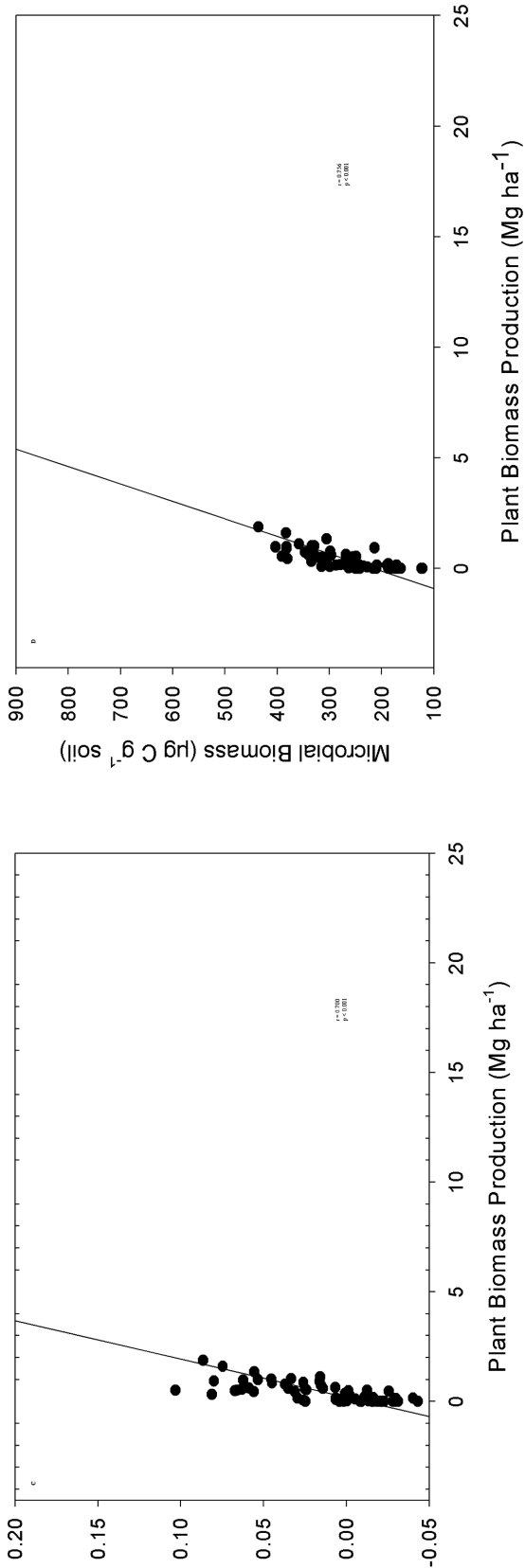

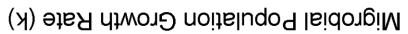

Fig. 15.3. Relationship between microbiological parameters (rate constant $k$ and microbial biomass) and plant biomass production. $\mathbf{A}$ and $\mathbf{B}$ represent biomass production of the first harvest and $\mathbf{C}$ and $\mathbf{D}$ biomass production of the fourth harvest 

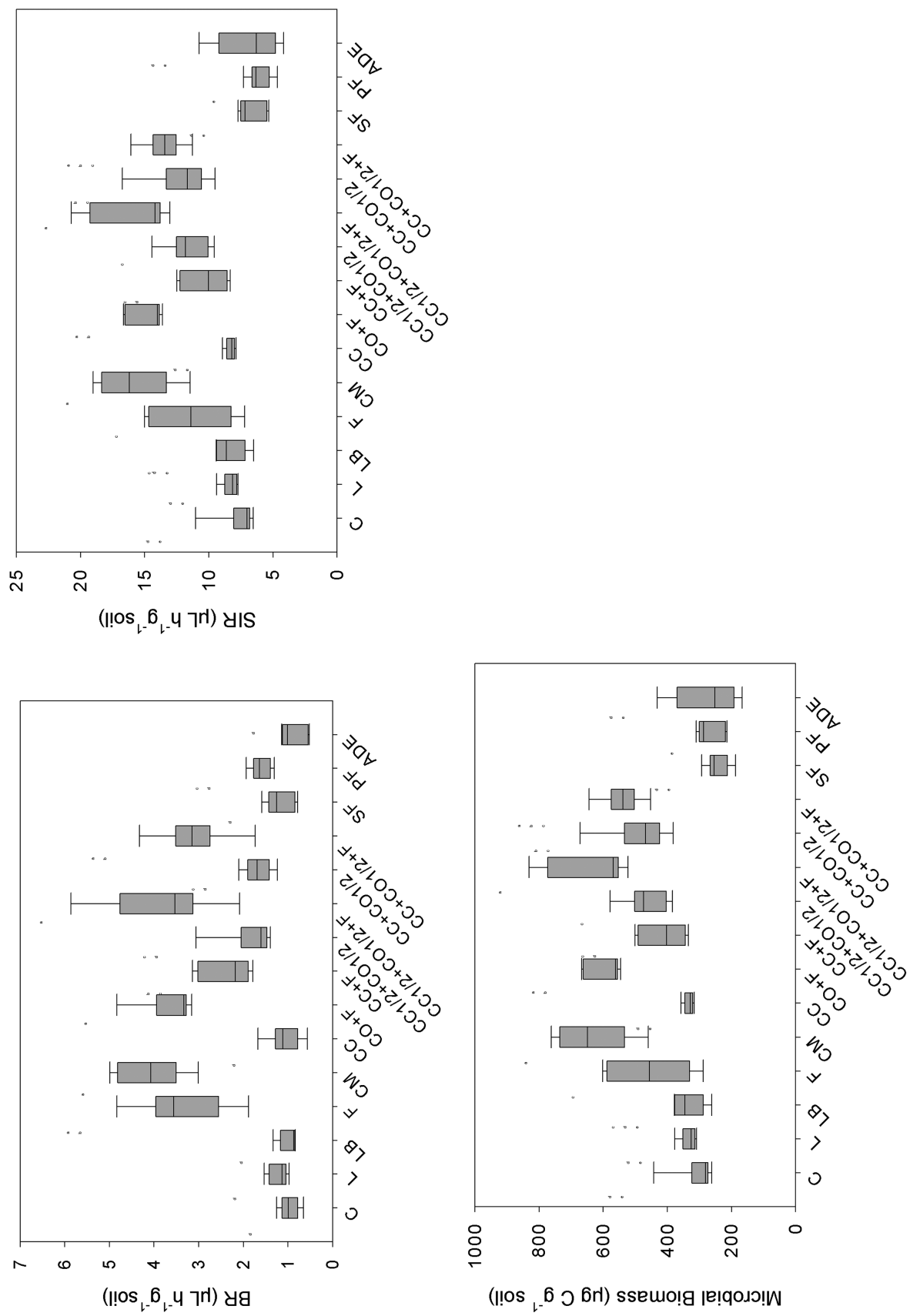

Fig. 15.4. Basal respiration $(B R)$, substrate-induced respiration $(S I R)$, and microbial biomass of Xanthic Ferralsols amended with different organic and inorganic fertilizers after the first year in comparison with secondary $(S F)$ and primary forest $(P F)$ soil as well as ADE soils. Significant differences are indicated by different letters $(p<0.05)$ 


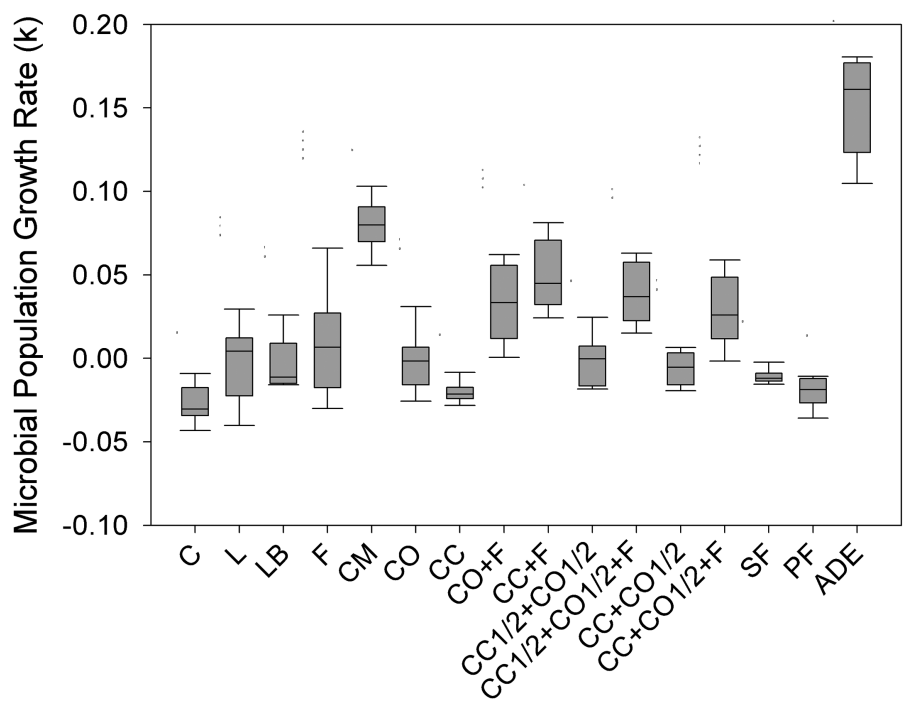

Fig. 15.5. Microbial population growth rate of Xanthic Ferralsols amended with different organic and inorganic fertilizers after the second year in comparison with secondary and primary forest soil as well as ADE soils. The reduction in $k$ is highest in mineral-fertilized soil. Population growth after substrate addition is significantly higher in the charcoal-amended and mineral-fertilized treatment $(C C+F)$ in comparison to the treatment mineral-fertilized alone without charcoal addition $(F)$. Significant differences between the groups are marked with letters $(p<0.05)$

explained either by the decomposition of the litter applied 20 months prior to measurement or by micronutrient fertilization. The effect of charcoal seems not to be a micronutrient supply, otherwise the treatment just amended with charcoal powder $\left(\mathrm{C}_{\mathrm{C}}\right)$ could not have a significantly lower $\mathrm{BR}$, and the population increase of treatment $\mathrm{L}$ is as low as in the other soils that were not amended with mineral fertilizer or chicken manure $\left(C, \mathrm{~L}_{\mathrm{B}}, \mathrm{C}_{\mathrm{O}}, \mathrm{C}_{\mathrm{C}}, \mathrm{C}_{\mathrm{C}}{ }^{1}{ }_{2}+\mathrm{C}_{\mathrm{O}}{ }^{1}\right.$ / 2, and $\mathrm{C}_{\mathrm{C}}+\mathrm{C}_{\mathrm{O}}{ }^{1} /{ }_{2}$ ).

The half-life of the rice litter shows a significant negative correlation with the plot's BR ( $r=-0.331, p=0.00984)$. Förster and Farias (2000) proved that litterbags buried in the soil reflect the soil's microbial activity much better than when distributed on the soil surface. The results of this litterbag study should not be overvalued, but a general trend shows that fertilized plots tend to have shorter half-lives than unfertilized plots. Significant differences were found between the treatment amended with compost and mineral fertilizer $\left(\mathrm{C}_{\mathrm{O}}+\mathrm{F}\right.$, mean 80 days) and the control ( $\mathrm{C}, 124$ days), litter (L, 118 days), charcoal $\left(\mathrm{C}_{\mathrm{C}}\right.$, 119 days), and charcoal+compost $\left(\mathrm{TC}_{\mathrm{C}}+\mathrm{C}_{\mathrm{O}}{ }^{1} / 2,114\right.$ days $)$. 


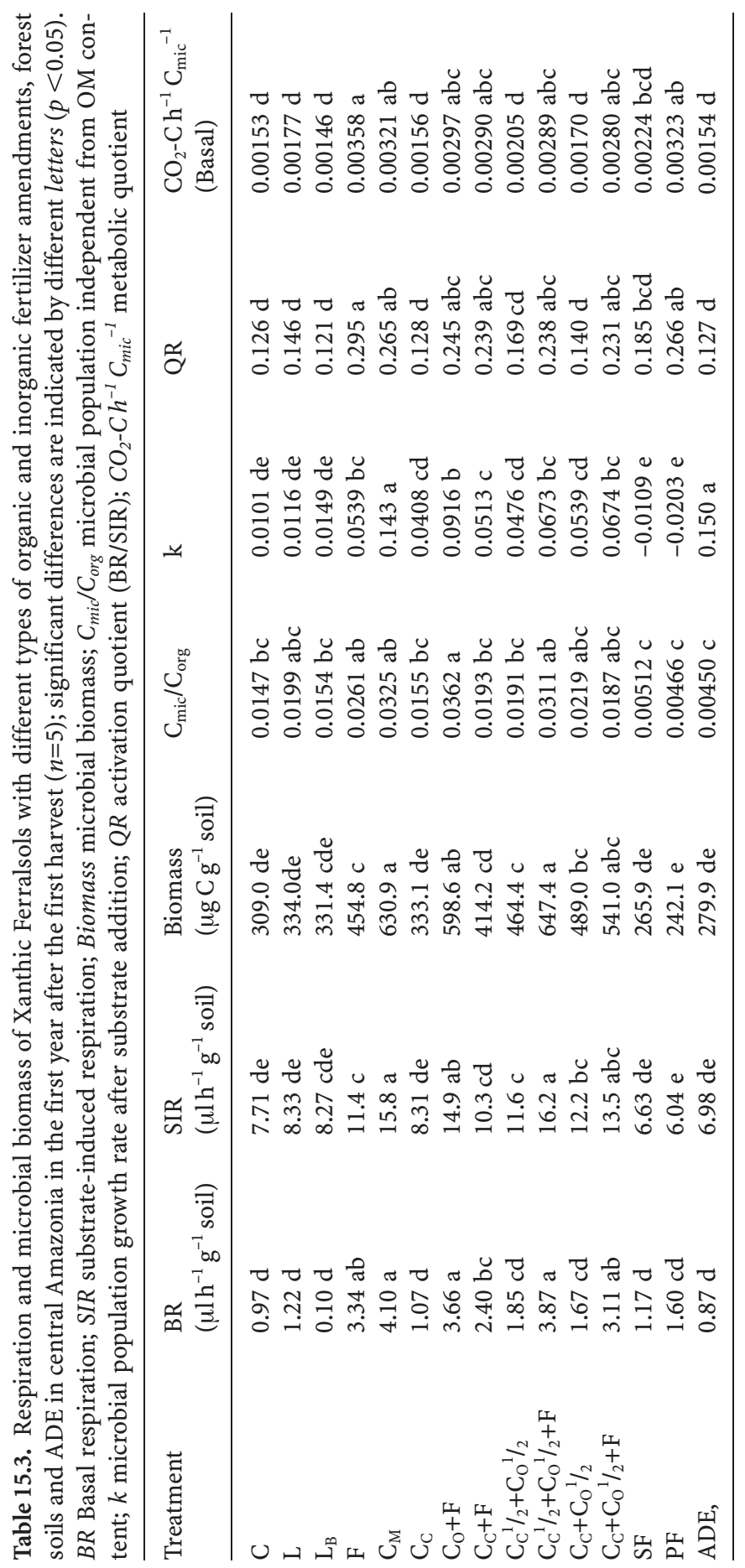




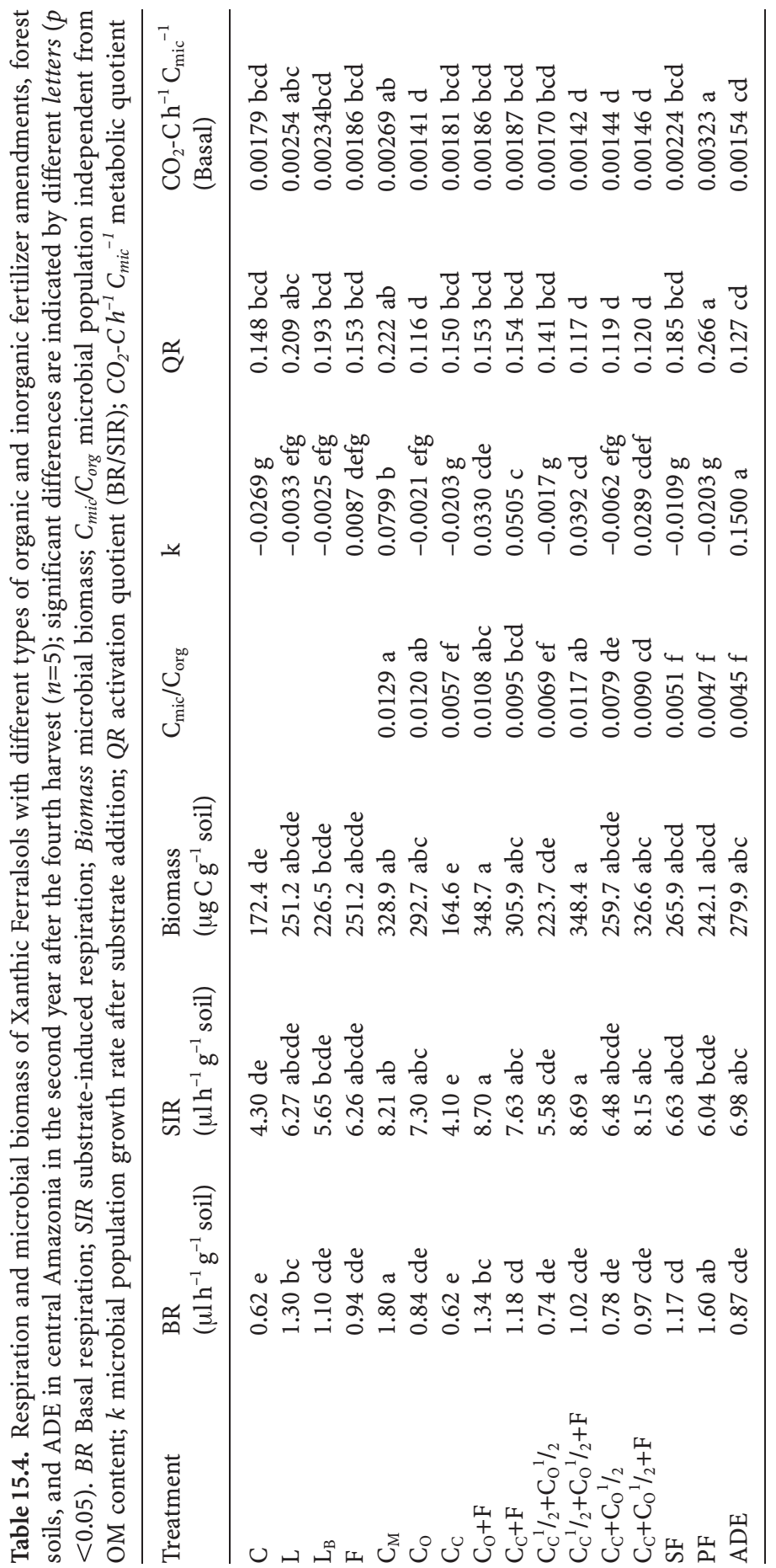




\section{4}

\section{Characteristics of ADE and Forest Soils}

Owing to a high OM content, primary forest (PF) soil has a high BR which is besides treatment $\mathrm{L}, \mathrm{C}_{\mathrm{M}}$, and $\mathrm{C}_{\mathrm{O}}+\mathrm{F}$ significantly higher than that of the other treatments compared in the second year. Compared to treatment L (litter) and $\mathrm{C}_{\mathrm{M}}$ (chicken manure), $\mathrm{PF}$ soil has a significantly increased respiratory quotient $(\mathrm{QR})$ and a significantly greater carbon turnover per unit of microbial biomass $\left(\mathrm{CO}_{2}-\mathrm{C} / \mathrm{C}_{\text {mic }} \mathrm{h}^{-1}\right)$ (Table 15.4).

$\mathrm{ADE}$ has low BR but high microbial population growth rates. The BR of $\mathrm{ADE}$ is significantly lower than that of soils amended with chicken manure $\left(\mathrm{C}_{\mathrm{M}}\right)$ and PF soils. However, the population increase after substrate addition is significantly higher than those of all treatments and forest soils apart from $\left(\mathrm{C}_{\mathrm{M}}\right)$. ADE and PF soils are both exceptional in comparison to the treatments. The plots show a positive correlation between BR and population growth rate, while it is negative in ADE and PF soils. PF soils are characterized by a relatively high $\mathrm{BR}$ and negative population growth and $\mathrm{ADE}$ by a very low $\mathrm{BR}$ but very high population growth after substrate addition (Fig. 15.6). These

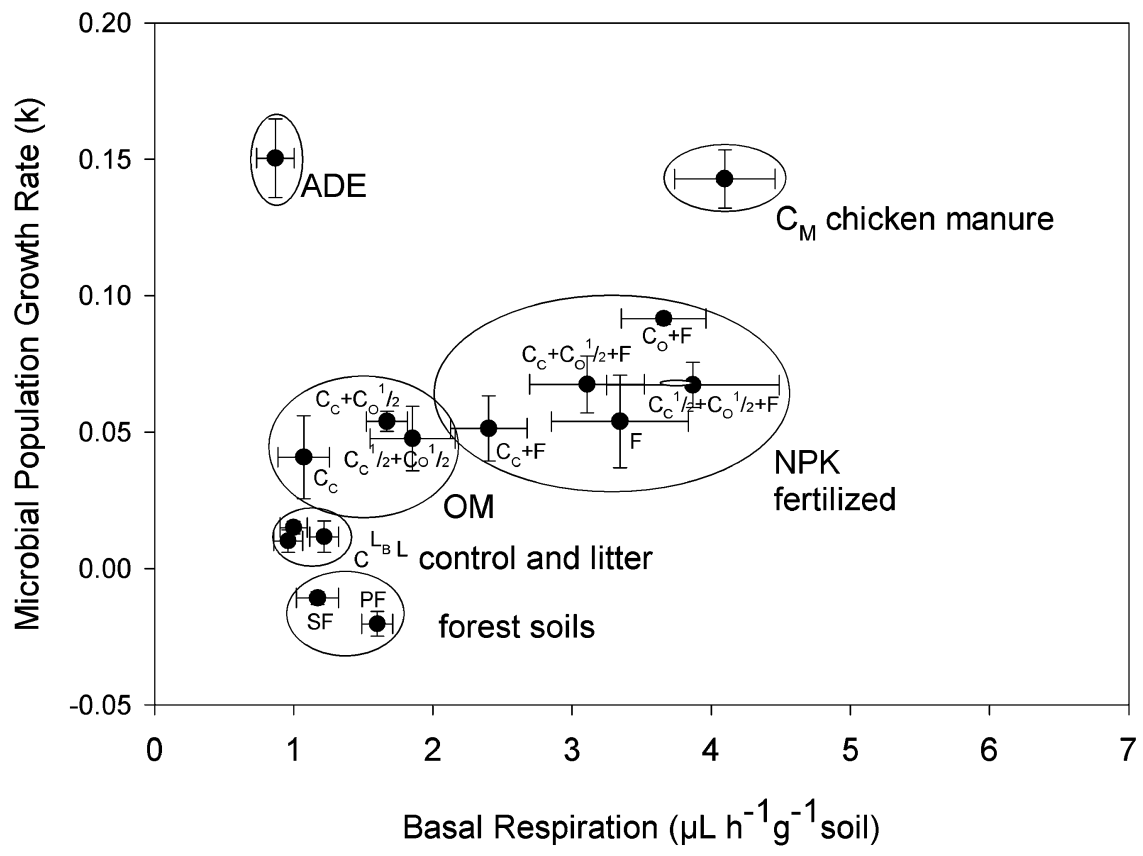

Fig. 15.6. Relationship between basal respiration and microbial population growth rate $(k)$ after the first harvest. ADEs are exceptional with a low basal respiration $(B R)$ and high growth rate. Primary forest $(P F)$ soil has relatively high BR but low $k$. Error bars indicate standard error of the mean ( $n=5$ for plot experiment; $n=5$ for secondary and primary forests; $n=5$ for ADE) 
results reflect the relatively high biodegradable OM content of PF topsoil but little available nutrients in contrast to high (mean 5.8\%, SD 1.4) nonbiodegradable stable ADE OM with high available nutrient contents. This is a characteristic of the tropical Oxisols under PF and in contrast to the exceptional anthropogenic ADE soils containing charcoal.

Acknowledgements. The research was conducted within SHIFT ENV 45, a German-Brazilian cooperation, and financed by BMBF, Germany, and CNPq, Brazil (BMBF no. 0339641 5A, CNPq 690003/98-6). The Austrian Academy of Sciences contributed financially. We are grateful for Bruno Glasers' (University of Bayreuth) valuable advice and for the fieldworkers' help particularly Luciana Ferreira da Silva and Franzisco Aragão Simão and the laboratory technician Marcia Pereira de Almeida. Special thanks for valuable information and introduction to the IRGAbased soil respiration analyses go to Bernhard Förster (ECT Oekotoxikologie, Germany) and Florian Raub (University of Karlsruhe, Germany).

\section{References}

Anderson JPE, Domsch KH (1978) A physiological method for the quantitative measurement of microbial biomass in soils. Soil Biol Biochem 10:125-221

Beck T, Bengel A (1992) Die mikrobielle Biomasse in Böden, Teil II. SuB Heft(2)

Braida WJ, Pignatello JJ, Lu YF, Rovikovitch PI, Neimark AV, Xing BS (2003) Sorption hysteresis of benzene in charcoal particles. Environ Sci Technol 37(2):409-417

Fageria NK (ed) (1998) Manejo da Calagem e Adubacao do Arroz. Tecnologia para o arroz de terras altas. Embrapa Arroz e Feijao, Santo Antonio de Goias, 67-79 pp

FAO (1990) Soil map of the world. FAO, Rome

Fischer Z, Bienkowski P (1999) Some remarks about the effect of smoke from charcoal kilns on soil degradation. Environ Monit Assess 58(3):349-358

Förster B, Farias M (2000) Microbial respiration and biomass. In: Beck L (ed) Soil fauna and litter decomposition in primary and secondary forests and a mixed culture system in Amazonia. Final report of project SHIFT ENV 52 (BMBF no 0339675). Staatliches Museum für Naturkunde, Karlsruhe, pp 59-64

Glaser B, Balashov E, Haumaier L, Guggenberger G, Zech W (2000) Black carbon in density fractions of anthropogenic soils of the Brazilian Amazon region. Organic Geochem 31:669-678

Glaser B, Haumaier L, Guggenberger G, Zech W (2001) The "terra preta" phenomenon: a model for sustainable agriculture in the humid tropics. Naturwissenschaften 88:37-41

Glaser B, Lehmann J, Zech W (2002) Amelioration physical and chemical properties of highly weathered soils in the tropics with charcoal - a review. Biol Fertil Soils 35:219-230

Goldammer JG (1993) Historical biogeography of fire: tropical and subtropical. In: Goldammer JG (ed) Fire in the environment: the ecological atmospheric, and climatic importance of vegetation fires. Wiley, New York, pp 297-314

Goudriaan J ()Global carbon and carbon sequestration. NATO ASI Ser 133

Kimura R, Nishio M (1989) Contribution of soil microorganisms to utilization of insoluble soil phosphorus by plants in grasslands. In: Proc 3rd Grassland Ecology Conf, Czechoslovakia, pp 10-17

Kuhlbusch TAJ. Crutzen PJ (1995) Toward a global estimate of black carbon in residues of vegetation fires representing a sink of atmospheric $\mathrm{CO}_{2}$ and a source of $\mathrm{O}_{2}$. Global Biogeochem Cycles 9:491-501

Kuhlbusch TAJ, Andreae MO, Cachier H, Goldammer JG, Lacaux J-P, Shea R, Cruzen PJ (1996) Black carbon formation by savanna fires: Measurements and implications for the global carbon cycle. J Geophys Res 101(D19):23651-23665 
Lehmann J, da Silva Jr, Pereira J, Rondon M, da Silva Cravo M, Greenwood J, Nehls T, Steiner C, Glaser B (2002) Slash and char - a feasible alternative for soil fertility management in the central Amazon? In: Proc 17th World Congr of Soil Science, Bangkok, Thailand, International Union of Soil Science, Pap 449, pp 1-12

Lehmann J, da Silva Jr, Pereira J, Steiner C, Nehls T, Zech W, Glaser B (2003) Nutrient availability and leaching in an archaeological Anthrosol and a Ferralsol of the central Amazon basin: fertilizers, manure and charcoal amendments. Plant Soil 249:343-357

Mehlich A (1984) Mehlich-3 soil test extractant: a modification of Mehlich-2 extractant. Commun Soil Sci Plant Anal 15:1409-1416

Nishio M (1996) Microbial fertilizers in Japan. FFTC-Extension Bulletins 1-12. National Institute of Agro-Environmental Sciences, Ibaraki, Japan

Pietikainen J, Kiikkila O, Fritze H (2000) Charcoal as a habitat for microbes and its effect on the microbial community of the underlying humus. Oikos 89(2):231-242

Saito M, Marumoto T (2002) Inoculation with arbuscular mycorrhizal fungi: the status quo in Japan and the future prospects. Plant Soil 244(1-2):273-279

Schmidt MWI, Noack AG (2000) Black carbon in soils and sediments: analysis, distribution, implications and current challenges. Global Biogeochem Cycles 14:777-793

Skjemstad J (2001) Charcoal and other resistant materials. In: Kirschbaum MUF, Mueller R (eds) Proc Net Ecosystem Exchange Worksh, Cooperative Research Centre for Greenhouse Accounting, Canberra, Australia, pp 116-119

Skjemstad JO, Clarke P, Taylor JA, Oades JM, McClure SG (1996) The chemistry and nature of protected carbon in soil. Aust J Soil Res 34(2):251-271

Steiner C, Teixeira WG, Zech W (2003) Slash and char - an alternative to slash and burn practiced in the Amazon Basin. In: Woods WI (ed) Explorations in Amazonian Dark Earths. Springer, Berlin Heidelberg New York

Stenström J, Stenberg B, Johanson M (1998) Kinetics of substrate-induced respiration (SIR): theory. Ambio 27(1):35-39

Trumbore SE, Chadwick OA, Amundson R (1996) Rapid exchange between soil carbon and atmospheric carbon dioxide driven by temperature change. Science 272:393-396

Uvarov AV (2000) Effects of smoke emissions from a charcoal kiln on the functioning of forest soil systems: a microcosm study. Environ Monitor Assess 60(3):337-357

Verburg PSJ, Dam Dv, Marinissen JCY, Westerhof R, Breemen Nv () The role of decomposition in C sequestration in ecosystems. NATO ASI Ser 133

Wardle DA, Zackrisson O, Nilsson MC (1998) The charcoal effect in Boreal forests: mechanisms and ecological consequences. Oecologia 115:419-426 